\title{
Effect of Foliar Application of 2,4-D, Urea and Zinc Sulphate on Fruit Drop, Yield and Fruit Quality of Kinnow Mandarin
}

\author{
Heerendra Prasad ${ }^{1 *}$, Manish Thakur ${ }^{1}$, Arun Kumar Gupta ${ }^{2}$, Dashrath Prasad $^{3}$ and Ajender ${ }^{1}$ \\ ${ }^{1}$ Dept. of Fruit Science, Dr. Y. S. P UHF Nauni, Solan, Himachal Pradesh (173 230), India \\ ${ }^{2}$ Division of water science and technology, IARI, New Delhi (110 012), India \\ ${ }^{3}$ SKRAU, Rajasthan (335 001), India
}

\section{Article History}

Manuscript No. AR1395

Received in $27^{\text {th }}$ June, 2015

Received in revised form $14^{\text {th }}$ September, 2015

Accepted in final form $5^{\text {th }}$ October, 2015

\section{Correspondence to}

${ }^{*}$ E-mail: heerendrasagar@gmail.com

\section{Keywords}

Kinnow, fruit drop, quality, urea, spray, zinc, 2,4-D

\begin{abstract}
The present investigation was carried out at Horticultural Regional Research Station, Dhaulakuan, Sirmour, of Dr. Y.S. Parmar University of Horticulture and Forestry, Nauni, Solan during the year 2011-2012 to evaluate the "Effect of foliar application of 2,4-D, urea and zinc sulphate on fruit drop, yield and fruit quality of Kinnow mandarin." The experiment was laid-down in Randomized Block Design (RBD) with eight treatments and three replications. The study comprises of one experiment in which Kinnow trees under investigation were subjected to treatments of $1 \%$ urea, $0.4 \%$ zinc sulphate, $20 \mathrm{ppm}$ 2,4-D (2,4-Dichloro phenoxy acetic acid synthetic auxin), urea $1 \%$ +zinc sulphate $0.4 \%$, urea $1 \%+2,4-\mathrm{D} 20 \mathrm{ppm}$, zinc sulphate $0.4 \%+2,4-\mathrm{D} 20$ ppm and urea $1 \%+$ zinc sulphate $0.4 \%+2,4-\mathrm{D}-20 \mathrm{ppm}$. The results revealed that the foliar application of $1 \%$ urea $+0.4 \%$ zinc sulphate $+2,4-\mathrm{D}-20 \mathrm{ppm}$ (part per million) resulted in highest in various Kinnow tree growth character (plant height $35.33 \mathrm{~cm}$, tree girth $2.81 \mathrm{~cm}$, shoot extension growth $20.43 \mathrm{~cm}$ and tree volume $31.42 \mathrm{~m}^{3}$ ), fruit retention $17.47 \%$, yield (509 Number of fruit plant ${ }^{-1}$ and $81.31 \mathrm{~kg} \mathrm{plant}^{-1}$ ) and fruit quality (fruit weight $159.83 \mathrm{gm}$, fruit breadth $7.03 \mathrm{~cm}$, fruit length $6.12 \mathrm{~cm}$, TSS (total soluble solids) 15.40 brix, and juice content $51.90 \%$ ), however lowest fruit drop $(81.31 \%)$ in comparison to other combination and control treatment.
\end{abstract}

\section{Introduction}

Citrus is grown through-out the world in tropical and subtropical climate, where there is suitable soil and sufficient moisture available to sustain the trees. Citrus is the second most important fruit crop after grapes in area and production in the world. It is grown in more than 100 countries under tropical, subtropical and Mediterranean climatic conditions. World citrus production is dominated by the northern hemisphere, followed by the southern hemisphere, and Mediterranean region. The mandarin occupies a prominent position and accounts for over $50 \%$ of the total area under citrus fruits. Kinnow, a mandarin hybrid of 'King' orange (Citrus nobilis Lour) and 'Willow leaf' mandarin (Citrus deliciosa Tenora) developed at California (USA) by H.B. Frost in 1935 (Rashid et al., 2005) is gaining popularity and its area under cultivation has increased manifolds in Punjab, Rajasthan, Haryana and Himachal Pradesh during the last 30 years. This area increase might have been due to its easy adaptability to varied agroclimatic conditions, heavy bearing and excellent juice quality characters which boosted its cultivation (Chundawat et al.,
1978). Due to higher fruit yield and excellent economic returns, citrus is becoming popular and area under cultivation is increasing in Himachal Pradesh. Kinnow mandarin though bear much amount of flower but only few hundred reach maturity due to excess flower and fruit drop at various stages of fruit development. In most citrus species, heavy fruit drop and occasional low fruit set are serious problems. This continued drop at various stages of fruit development results in considerable reduction in yield and leads to low profit to citrus growers. However, the intensity of fruit drop in Kinnow mandarin is dependent on soil moisture, climate and environmental conditions of a particular locality which exercise a marked influence on the effectiveness of plant growth regulators and other chemicals for its control.

\section{Materials and Methods}

The experimental trail was carried out at the Horticultural Regional Research Station, Dhaulakuan Himachal Pradesh during the year 2011-12 that have climate is humid subtropical type with May and June being the hottest months whereas, 
December and January being the coldest months. Horticulture Regional Research Station, Dhaulakuan is located between $35.5^{\circ} \mathrm{N}$ latitude and $77.5^{\circ} \mathrm{E}$ longitude at an elevation of 468 meters above mean sea level. The present studies were carried out on fifteen year old plants budded on Jatti Khatti (Citrus jambhiri) rootstock. The application of the foliar spray concentration and time in the as per as Table 1.

There are following observations were recorded on the basis various parameters i.e. tree height, trunk girth, shoot extension growth, tree volume, fruit drop (fruit drop $\%=$ total number of dropped fruit/total number of fruit set $\times 100$ ), fruit retention (fruit retention $\%=$ total number of fruit at harvest/total number of fruit set $\times 100)$, fruit size $(\mathrm{cm})$, fruit weight $(\mathrm{g})$, yield plant ${ }^{-1}$ $(\mathrm{kg})$, Titratable Acidity (\%), Juice content (\%) and Total

\begin{tabular}{|c|c|c|c|c|}
\hline $\begin{array}{l}\text { Sl. } \\
\text { no. }\end{array}$ & $\begin{array}{c}\text { Time of } \\
\text { application }\end{array}$ & $\begin{array}{c}\text { Concen- } \\
\text { tration }\end{array}$ & $1^{\text {st }}$ spray & $2^{\text {nd }}$ spray \\
\hline 1. & Urea & $1 \%$ & $\begin{array}{c}\left(1^{\text {st }} \text { week }\right) \\
\text { April }\end{array}$ & $\begin{array}{l}\left(1^{\text {st }} \text { week }\right) \\
\text { September }\end{array}$ \\
\hline 2. & $\begin{array}{c}\text { Zinc } \\
\text { Sulphate }\end{array}$ & $0.4 \%$ & $\begin{array}{c}\left(2^{\text {nd }} \text { week }\right) \\
\text { April }\end{array}$ & $\begin{array}{l}\left(2^{\text {nd }} \text { week }\right) \\
\text { September }\end{array}$ \\
\hline 3. & 2,4-D & $20 \mathrm{ppm}$ & $\begin{array}{c}\left(2^{\text {nd }} \text { week }\right) \\
\text { May }\end{array}$ & $\begin{array}{l}\left(2^{\text {nd }} \text { week }\right) \\
\text { September }\end{array}$ \\
\hline
\end{tabular}

soluble solid ( ${ }^{\circ}$ Brix).

\section{Results and Discussion}

\subsection{Effect of foliar application growth characters}

The effect of different treatments on increment in tree height of Kinnow is increased the tree height as compared to control but Urea $+\mathrm{ZnSO}_{4}+2,4-\mathrm{D}$ showed maximum increment in tree height $(35.33 \mathrm{~cm})$ (Table 2). The minimum increment in tree height was observed under control $(20.33 \mathrm{~cm})$. Maximum increment in trunk girth $(2.81 \mathrm{~cm})$ was recorded with Urea $+\mathrm{ZnSO}_{4}+2,4-\mathrm{D}$ treatment. Minimum increment in trunk girth was observed under control $(2.23 \mathrm{~cm})$. Perusal of data reveals that maximum tree volume $\left(31.42 \mathrm{~m}^{3}\right)$ was recorded under treatment $\mathrm{Urea}+\mathrm{ZnSO}_{4}+2,4-\mathrm{D}$. the minimum increment in tree volume was observed under control $\left(27.96 \mathrm{~m}^{3}\right)$. All the treatments increased the shoot extension growth of Kinnow trees over the control. The maximum shoot extension growth $(20.43 \mathrm{~cm})$ was observed with Urea $+\mathrm{ZnSO}_{4}+2$, 4-D treatment However, the minimum shoot extension growth was recorded under control $(15.79 \mathrm{~cm})$.

The application of urea $+\mathrm{ZnSO}_{4}+2,4-\mathrm{D}$ caused maximum increment in tree height, trunk girth, tree volume and shoot extension growth. This increase in growth characters might be due to the fact that nitrogen is an integral part of chlorophyll which primarily absorbs light energy needed for photosynthesis, so it may be attributed to higher photosynthetic efficiency. These observations are also in conformity with the finding of several other workers, who have also reported that urea increase tree growth of oranges and Kinnow mandarin (Malik et al., 2000). The increase in the tree height perhaps was brought about by an increase in the dimensions of individual cell both in pith and cortex region. These observations are also in conformity with the findings of other workers, who have also reported that nitrogen fertilization increase tree growth in citrus (Rathore and Chandra, 2003).

Increase in tree growth in treated trees might be due to active involvement of $\mathrm{Zn}$ in the synthesis of tryptophan which is a precursor of Indole acetic acid synthesis; consequently it increased tissue growth and development (Swietlik, 1999). It has also been reported that sufficient level of $\mathrm{Zn}$ is plants promote the photosynthesis, nucleic acid metabolism and protein biosynthesis. Our results are in agreement with the

Table 2: Effect of foliar application of 2,4-D, urea, zinc sulphate and their combinations on fruit tree growth characteristics, fruit set, fruit drop and fruit retention of Kinnow mandarin

\begin{tabular}{|c|c|c|c|c|c|c|}
\hline Treatment & $\begin{array}{l}\text { Tree height } \\
(\mathrm{cm})\end{array}$ & $\begin{array}{c}\text { Trunk } \\
\text { girth }(\mathrm{cm})\end{array}$ & $\begin{array}{l}\text { Tree volume } \\
\qquad\left(\mathrm{m}^{3}\right)\end{array}$ & $\begin{array}{l}\text { Shoot extension } \\
\text { growth }(\mathrm{cm})\end{array}$ & $\begin{array}{l}\text { Fruit drop } \\
\quad(\%)\end{array}$ & $\begin{array}{c}\text { Fruit } \\
\text { retention }(\%)\end{array}$ \\
\hline Urea $(1 \%)$ & 29.67 & 2.61 & 29.22 & 19.64 & $89.23(9.45)$ & $10.77(3.28)$ \\
\hline $\mathrm{ZnSO}_{4}(\mathrm{O} .4 \%)$ & 24.00 & 2.49 & 28.54 & 17.85 & $89.30(9.45)$ & $10.70(3.27)$ \\
\hline $2,4-\mathrm{D}(20 \mathrm{ppm})$ & 23.33 & 2.32 & 28.30 & 16.64 & $86.87(9.32)$ & $13.13(3.62)$ \\
\hline Urea $-1 \%+\mathrm{ZnSO}_{4}(0.4 \%)$ & 27.67 & 2.67 & 29.66 & 19.96 & $87.56(9.36)$ & $12.43(3.53)$ \\
\hline Urea-1\%+2,4-D (20 ppm) & 28.00 & 2.42 & 29.96 & 18.30 & $85.93(9.27)$ & $14.07(3.75)$ \\
\hline $\mathrm{ZnSO}_{4}-0.4 \%+2,4-\mathrm{D}(20 \mathrm{ppm})$ & 25.67 & 2.39 & 28.57 & 17.33 & $88.10(9.39)$ & $11.90(3.45)$ \\
\hline $\begin{array}{l}\text { Urea- } 1 \%+\mathrm{ZnSO}_{4}(0.4 \%+2,4- \\
\mathrm{D}(20 \mathrm{ppm})\end{array}$ & 35.33 & 2.81 & 31.42 & 20.43 & $82.53(9.08)$ & $17.47(4.18)$ \\
\hline Control & 20.33 & 2.23 & 27.96 & 15.79 & $94.23(9.71)$ & $5.77(2.40)$ \\
\hline
\end{tabular}


finding of Dawood et al. (2001) who also reported increase in growth of Washington Navel orange with $\mathrm{Zn}$ application.

\subsection{Effect of foliar application on Fruit retention}

Maximum fruit retention (17.47\%) was observed in Urea $+\mathrm{ZnSO}_{4}+2,4-\mathrm{D}$ treatment and minimum fruit retention $(5.77 \%)$ was observed under control. During the study, foliar application of nutrients had significant effect on fruit retention, but the maximum fruit retention at the time of harvest was observed with 2,4-D+Urea+Zinc sulphate treatment. The mentioned results are in harmony with those obtained for fruit retention by Nirmaljit et al. (2000). They also reported that the highest fruit drop control was exhibited by spraying 2,4-D at $20 \mathrm{ppm}$ after fruit set and found the maximum fruit retention. Similar finding were given by Malik et al. (2000) who reported that urea reduced fruit drop and increased fruit retention which might have given higher number of fruits and consequently higher yield. This may be due to nitrogen being an important component of protoplasm and chlorophyll molecule, which might have increased photosynthetic efficiency of trees and consequently the yield.

\subsection{Effect of foliar application on Yield}

The data enumerated in that maximum yield $(81.31 \mathrm{~kg})$ was recorded under Urea $+\mathrm{ZnSO}_{4}+2,4-\mathrm{D}$ treatment (Table 3). However, minimum yield $(51.41 \mathrm{~kg})$ was obtained in control. Increase in yield might be due to an increase in fruit retention and decrease in fruit drop by the same treatment. Similar increase in citrus fruit tree yield with urea spray was reported by Rathore and Chandra (2003) and with 2,4-D sprays by Nirmaljit et al. (2000); Babu and Yadav (2007). The significant effect of zinc in increasing number of fruit and yield might be due to the synthesis of tryptophan which serves as precursor for auxin synthesis. The increase in fruit number might be due to reduction in fruit drop. Thomas and Lovatt (2004) also reported that pre-harvest application of growth regulators like 2,4-D significantly increase the total number of fruit at the time of harvest and fruit weight plant ${ }^{-1}$ by reducing the pre-harvest fruit drop.

\subsection{Effect of foliar application on fruit size and weight of Kinnow}

Highest fruit weight (159.83 g) was recorded with treatment Urea $+\mathrm{ZnSO}_{4}+2,4-\mathrm{D}$ which was significantly superior to all other treatments. However, lowest fruit weight was observed under control (128.17 g).The effects of different treatments reveal that fruit length of Kinnow was not affected significantly. However maximum fruit length $(6.12 \mathrm{~cm})$ was in treatment Urea $+\mathrm{ZnSO}_{4}+2,4-\mathrm{D}$ Minimum Kinnow fruit length $(5.37 \mathrm{~cm})$ was recorded under control.

Maximum fruit breadth $(7.03 \mathrm{~cm})$ was recorded under $\mathrm{Urea}+\mathrm{ZnSO}_{4}+2,4-\mathrm{D}$ treatment Minimum fruit breadth was recorded under control $(6.10 \mathrm{~cm})$. Urea $+\mathrm{ZnSO}_{4}+2,4-\mathrm{D}$ treatment enhanced the fruit growth significantly as compared to other treatments. Urea is known to encourage vegetative growth and thus, increase photosynthesis efficiency and accumulation of carbohydrate needed for fruit growth. Stern et al. (2007) held the same view; they observed 8-13@ increase in fruit diameter due to auxin application. This could be attributed to the formation of phloem and secondary xylem which they deemed to be directly related to fruit size. Increase in fruit weight, fruit size and juice content was observed as maximum in 2,4-D (20 ppm) treatment (Nirmaljit et al., 2000). The zinc is also required for the synthesis of tryptophan, a precursor for the synthesis of Indole acetic acid, which is involved in the process of fruit growth and development.

\subsection{Effect of foliar application on Juice content (\%)}

Maximum juice content (51.90\%) was observed with Urea $+\mathrm{ZnSO}_{4}+2,4-\mathrm{D}$ treatment which was closely followed by Urea $+\mathrm{ZnSO}_{4}$ (48.01\%). However, the minimum juice content was observed under control (43.16\%). Combined application

Table 3: Effect of foliar application of 2,4-D, urea, zinc sulphate and their combinations on fruit yield, weight and fruit size of Kinnow mandarin

\begin{tabular}{|c|c|c|c|c|c|c|c|c|}
\hline Treatment & $\begin{array}{l}\text { Fruit yield } \\
\left(\mathrm{kg} \text { tree }^{-1}\right)\end{array}$ & $\begin{array}{l}\text { Fruit yield } \\
\left(\text { No. tree }^{-1}\right)\end{array}$ & $\begin{array}{l}\text { Fruit } \\
\text { weight } \\
\text { (gm) }\end{array}$ & $\begin{array}{l}\text { Fruit } \\
\text { length } \\
(\mathrm{cm})\end{array}$ & $\begin{array}{c}\text { Fruit } \\
\text { breadth } \\
(\mathrm{cm})\end{array}$ & $\begin{array}{l}\text { Juice } \\
(\%)\end{array}$ & $\begin{array}{c}\text { TSS } \\
\left({ }^{\circ} \text { Brix }\right)\end{array}$ & $\begin{array}{c}\text { Titratable } \\
\text { acidity }(\%)\end{array}$ \\
\hline Urea $(1 \%)$ & 54.66 & 436 & 133.44 & 5.49 & 6.19 & 46.01 & 13.93 & 1.04 \\
\hline $\mathrm{ZnSO}_{4}(\mathrm{O} .4 \%)$ & 57.63 & 422 & 136.00 & 5.62 & 6.51 & 44.40 & 14.10 & 1.06 \\
\hline 2,4-D (20 ppm) & 59.19 & 468 & 135.50 & 5.65 & 6.63 & 47.22 & 14.20 & 1.07 \\
\hline Urea $-1 \%+\mathrm{ZnSO}_{4}(0.4 \%)$ & 62.83 & 443 & 142.00 & 5.83 & 6.67 & 48.01 & 14.47 & 1.02 \\
\hline Urea-1\%+2,4-D (20 ppm) & 66.69 & 473 & 140.83 & 5.76 & 6.78 & 47.97 & 14.13 & 1.05 \\
\hline $\mathrm{ZnSO}_{4}-0.4 \%+2,4-\mathrm{D}(20 \mathrm{ppm})$ & 72.10 & 485 & 148.50 & 5.82 & 6.93 & 46.61 & 14.67 & 1.03 \\
\hline $\begin{array}{l}\text { Urea- } 1 \%+\mathrm{ZnSO}_{4}(0.4 \% \\
+2,4-\mathrm{D}(20 \mathrm{ppm})\end{array}$ & 81.31 & 509 & 159.83 & 6.12 & 7.03 & 51.90 & 15.40 & 1.01 \\
\hline Control & 51.41 & 410 & 128.17 & 5.37 & 6.10 & 43.16 & 13.63 & 1.09 \\
\hline
\end{tabular}


of Urea $+\mathrm{ZnSO}_{4}+2,4-\mathrm{D}$ increased the juice percentage of Kinnow. These results are in line with Malik et al. (2000) who also reported the maximum juice in fruits from the trees sprayed with the zinc and urea combination. Similar observation were recorded by Babu and Yadav (2005) who also reported maximum juice content in fruits that sprayed with zinc. The results regarding high juice percentage over control are in consonance with that of Malthew et al. (2002) who also reported that the application of growth regulators at flowering and pre-harvest stage significantly increased the juice per cent in various citrus fruit.

\subsection{Effect of foliar application on Total soluble solid ( ${ }^{\circ}$ Brix)}

The data on the effect of different treatments on fruit TSS of Kinnow increased as compared to control but Urea $+\mathrm{ZnSO}_{4}+2,4-\mathrm{D}$ treatment recorded maximum TSS (15.4 ${ }^{\circ}$ Brix ). The minimum total soluble solid content was observed under control (13.63 ${ }^{\circ}$ Brix). The increase in total soluble solids as a result of urea and $\mathrm{Zn}$ spray might be ascribed to the increased photosynthesis and production of more assimilates due to auxin synthesis Results are also in consonance with that of Huang and Huang (2005) who also reported that by application of growth regulators like auxin, TSS increased significantly in citrus fruit species.

\subsection{Effect of foliar application on titratable acidity (\%)}

Higher fruit titratable acidity (1.09\%) was recorded under control treatment which was statistically at par with 2,4-D (1.07\%) and $\mathrm{ZnSO}_{4}$ (1.06) treatments. However, the minimum titratable acidity was recorded under Urea $+\mathrm{ZnSO}_{4}+2,4-\mathrm{D}$ $(1.01 \%)$ treatment. Fruit juice acidity was significantly decreased with Urea+Zinc Sulphate+2,4-D treatments as compared with other treatments. Malik et al. (2000) also reported the minimum acidity with zinc and urea combination. Results related to acidity per cent of fruit were also found to be in close agreement with that of El-Otmani et al. (2004) and Xiao et al. (2005) who also reported that by the application of 2,4-D and other auxin growth regulators, acidity per cent was significantly reduced.

\section{Conclusion}

Maximum growth, fruit retention, yield and fruit quality was observed in treatment Urea $+\mathrm{ZnSO}_{4}+2,4-\mathrm{D}$. Hence, it can be suggested that the foliar application of Urea $+\mathrm{ZnSO}_{4}+2,4-\mathrm{D}$ may be given at fruit set stage and again in September to reduce fruit drop and for enhance growth, yield and fruit quality of Kinnow mandarin.

\section{References}

Babu, K.D., Yadav, D.S., 2007. Foliar spray of micronutrients for yield and quality improvement in Khasi mandarin (Citrus reticulate Blanco.). Indian Journal of Horticulture 62, 280-
281.

Chundawat, B.S., Gupta, A.K., Singh, B.P., 1978. Storage behavior of different grades of Kinnow fruit. Punjab Horticulture Journal 18,156-160.

Davies, J.P., 1995. Plant Hormones. $2^{\text {nd }}$ Ed. In: Kluwer Academic Publishers, USA.

Dawood, S. A., Meligy, M.S., El-Hamady M.M., 2001. Influence of zinc sulphate application on tree leaf and fruit characters of three young citrus verities grown on slightly alkaline soil. Annals of Agriculture Science 39, 433-447.

El-Otmani, M., Taibi, F.Z., Lmoufid, B., Ait-Oubahou, A., Lovatt, C.J., 2004. Improved use of foliar urea on clementine mandarin to manipulate cropping in a sustainable production system. Acta Horticulturae 632, 167-175.

Huang, J.H., Huang, L., 2005. The application of GA3 in citrus orchard. Journal of South china fruits 3, 32-36.

Malik, R.P., Ahlawat, V.P., Nain, A.S., 2000. Effect of foliar spray of urea and zinc sulphate on yield and fruit quality of Kinnow-a mandarin hybrid. Haryana Journal of Horticultural Sciences 29(1-2), 37-38.

Malthew, W.F., Davis, F.S., 2002. Gibberellic acid application timing affects fruit quality of processing oranges. Horticultral Science 37, 353-357.

Modise, D.M., Likuku, A.S., Thuma, M., Phuti, R., 2009. The influence of exogenously applied 2,4-dichlorophenoxyacetic acid on fruit drop and quality of Naval oranges (Citrus sinensis L.). African journal of Biotechnology 8, 2131-2137.

Nirmajit, K., Monga, P.K., Thind, S.K., Thatai,V.K., Vij., Kaur, N., 2000. Effect of growth regulators on periodical fruit drop in Kinnow mandarin. Haryana Journal of Horticultural Sciences 29, 39-41.

Rashid, M., Khan, M.M., Fatima, B., Abbas, M., Adnan, S., 2005. In vitro shoot regeneration and multiple shoots induction in Citrus reticulate. Journal of Tissue Research 7, 414-416.

Rathore, R.S., Chandra, A., 2003. Effect of application of nitrogen in combination with zinc sulphate on vegetative growth characteristics of acid lime (Citrus aurantifolia Swingle) cv. Kazi lime. Agriculture Science Digest 23(3), 220-222.

Stern, R.A., Flaishman, M., Ben-Arie, R., 2007. The effect of Synthetic auxins on fruit development, quality and final fruit size in 'Canino apricot'(Prunus armeniaca L.). Journal of Horticultural Science and Biotechnology 82(2), 335-340.

Swietlik, D., 1999. Zinc nutrition in horticultural crops. In: J. Janick (Ed.), Horticultural Reviews. John Wiley and Sons, 109-118.

Thomas, C.C., Lovatt, C., 2004. Application of plant growth regulators and/or fertilizers to increase fruit set, fruit size and yield of Clementine mandarin. Citrus research board. Annual report. Botany and plant sciences.

Xiao, J.X., Beng, S., He Hua-ping, Li Jiang-Hai, 2005. Effect of calcium nitrate and IAA on calcium concentration and quality of Satsuma mandarin fruit. Journal of Fruit Science 22(3), 211-215. 